\title{
Jeje-Adang's Capital Relations in Local Election of Pangandaran Regency
}

\author{
${ }^{1}$ RATNIA SOLIHAH, ${ }^{2}$ ARRY BAINUS, ${ }^{3}$ MUDIYATI RAHMATUNNISA \\ ${ }^{1}$ Department of Political Science, UNPAD, Sumedang, 2Department of International Relation, UNPAD, Sumedang, \\ ${ }^{3}$ Department od Political Science, UNPAD, Sumedang

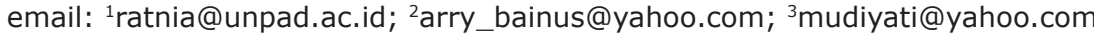

\begin{abstract}
The study of Jeje-Adang's capital relations in Pangandaran Regency election aims to analyze the influence of one capital to other capital ownership process which ultimately plays a role in winning political contestation. This study uses qualitative approach with descriptive method through field studies by means of interviews, documentation, and literature studies. The study results indicate a relationship between political capital, economic capital, and Jeje-Adang's social capital in local election of Pangandaran Regency. In this relation, the utilization of social capital contributes to the acquisition of Jeje-Adang's political and economic capital. Enhancement of the pair's social capital is due to the use of political capital through their involvement in politics and government and the utilization of economic capital as entrepreneurs prior to the election. Thus, the relationship between political capital, social capital, and economic capital of Jeje-Adang is contributed to their winning in Pangandaran Regency election.
\end{abstract}

Keywords: social capital, political capital, economy capital, local election

\section{Introduction}

The process of direct local election can be described as political contestation which contains capital competition between regional head candidates and the deputy head who participate in the election. This is in line with Bourdieu's thought (1986) that capital is closely related to the issue of power. Bourdieu's point of departure in constructing his capital theory is the problem of domination. In a political society, domination is one of the main issues as a form of power actualization. This domination depends on the situation, resources (capital), and strategy of the actor. Mapping the power relation is based on ownership and the composition of capital (Haryatmoko, 2011). Capital ownership in elections, particularly in local election of Pangandaran Regency, is interesting to be studied in line with the anxiety of many parties over the high capital in the election and problems arise related to the capital.

In this study, the high cost of capital in local elections is not only determined by money (material), but also by non-material, namely political support from political parties or coalitions of political parties which influenced by the ability, capacity, and political character of the candidates along with the role of candidate's winning team, support from volunteers and social community groups, and voters' trust on the candidates.

The local election of Pangandaran Regency in 2015 was the first local political contestation held in the newly expanded Ciamis Regency in 2013. The local political contestations for the Regent-Deputy Regent were followed by 3 (three) pairs of candidates, namely $\mathrm{H}$. Ino Darsono - Dr. Erwin Thamrin, $\mathrm{Hj}$ Azizah Talita Dewi, S.Sos., MM - Sulaksana, ST, MT, and H. Jeje Wiradinata - H. Adang Hadari. In the political contestation, $\mathrm{H}$. Ino Darsono - dr. Erwin Thamrin gained 75,778 votes; Hj. Azizah Talita Dewi, S.Sos., MM Sulaksana, ST, MT gained 23,216 votes; and $\mathrm{H}$. Jeje Wiradinata - H. Adang Hadari gained 140,481 votes. Based on the votes, $H$. Jeje Wiradinata - H. Adang Hadari gained $58.66 \%$ of the total valid votes and acclaimed as the winner of local election of Pangandaran Regency in 2015 (KPU of Pangandaran Regency, 2016: 91).

Received: April 10, 2018, Revision: Agustus 20, 2018, Accepted: December 14, 2018

Print ISSN: 0215-8175; Online ISSN: 2303-2499. DOI: http://dx.doi.org/10.29313/mimbar.v34i2.3671.378-388

Accredited B based on the decree No.040/P/2014, valid on February, 18, 2014 until February, 18, 2019. Indexed by DOAJ, Sinta, IPI. 
The success of gaining more than $50 \%$ votes in local election of Pangandaran Regency showed a high level of public trust for Jeje-Adang to become a regional leader in Pangandaran Regency. The success of this candidate in winning significant votes, one of which, was determined by the ownership and use of political, economic, and social capital, along with the accumulation and relationship between these capitals in optimizing vote acquisition, which subsequently gave the candidate a victory to became Regent and Deputy Regent of Pangandaran Regency for the period of 2016-2021.

The studies of capital in political context, among others, are carried out by Booth and Richard (1997) who see the effects of civil society, political capital, and democratization on the level of democracy in Central America; and study of Birner and Wittmer (2007) who raised the case of converting social capital into political capital in Thailand and Columbia. To review their study, Birner and Witmer made a concept of political capital which examine how local communities use social capital to achieve political results through political activities, such as vote mobilization, direct participation in legislative processes, protests/demonstrations, lobbying, and building discourse (as political capital) to create democracy.

In some studies of local elections with political economic perspective which include the study of capital in political contestation (capital in the elections), most researchers focus more on one capital (such as political capital, economic capital, social capital, cultural capital) and only describe one or several capitals owned by the regent and deputy regent candidate pair in the election (among others, Arwantinna, 2013; Putra, 2012; Pantouw, 2012; Rasyid, 2012; Agusyanto, 2011). Whereas, this study focuses on the relationship between political capital, economic capital, and social capital owned by Jeje-Adang which determined their victory in election.

Based on the above description, researchers are interested to conduct a study of Relationship between Political Capital, Economic Capital and Social Capital of Jeje-Adang in local election of Pangandaran Regency in 2015. The highlight of this study is to analyze how one capital contributes and influences other capital ownership processes, which finally played a role in winning the political contestation.
There are several forms of capital in political contestation (local elections). By constructing the capital concept of Bourdieu (1986), Marijan (2006), and Casey (2008), basically candidates must at least have political capital, economic capital, and social capital to be succeeded in political contestation.

According to Marijan (2006: 89), the direct local election process can be described as political contestation which requires 3 main capitals from each candidate who will compete in the election. Those three capitals aforementioned are political, social, and economic capital which can influence a candidate in obtaining support from the community. The greater accumulation of capitals owned by a candidate, the greater support would be obtained.

Marijan argues that political capital is political support from both the people and political forces which seen as people's representation (2010: 184-185). Casey defines political capital as the use of all types of capital owned by political actors or institutions to produce beneficial political actions and strengthen the position of political actors/institutions concerned (2008: 7). Political capital can also be in a form of support from political organizations and community organizations for local political elites that influence the victory and political positions which affect the community (Nurhasim, 2003: 8). Hick and Misra (Pantouw, 2012) argue that political capital is sharing the focus of giving the power or resources to actualize things that can create interest. In essence, political capital is the power a person has which can be operated or contributed to the success of his contestation in political process such as elections.

Thus, political capital can be concluded as political support from political forces. It is also the utilization of all types of capital owned by political actors/institutions to produce political actions that benefit and strengthen their positions so that their political reputation is in the viewpoint of people outside, especially those of potential voters. In addition, political capital is also the power a person has (his/ her political capacity and experience, as well as political and strategic position in political institutions) which can be operated or contributed to the success in political processes such as elections.

In electoral contestation, the role of political capital shows that political parties can 
function as entry points for the candidates, particularly for those who are not party cadres, and in the meantime the parties fail to find competent figures regarding political funding (economic capital) and political support from voters (social capital).

Economic capital is a political fund greatly needed by candidates and the winning team to finance all stages of the election. The role of economic capital (political funds) is a driver of political machinery which can determine the winning strategy implemented by each candidate and his winning team, especially to finance various operational needs of campaign activities.

Political fund is economic capital that should be possessed by the candidates to compete and succeed in political contestation (local elections). This political fund can be seen through the source of its acquisition and use as it stated by Sahdan and Haboddin (2009: 124-125), that (1) Viewed from the source, political funds come from candidates' contributions and donations from donors, both individually and companies. Political funds can also be interpreted as concrete manifestations of community participation and support for the candidates; (2) In terms of use, political funds are differentiated based on the form of allocation of expenditure: to finance political party's routine activities and campaign expenditures.

The amount of political funds used by candidates and the winning team does not necessarily guarantee they will win the election. Some local elections show that public confidence in choosing a candidate is not always directly proportional to the cost spent by candidates. In political contestation, besides being supported by political funds (economic capital), candidates are also assessed by their figures and morality, as well as the role of social networks, political support from voters, and the influence of social and economic actors.

Social capital has an equal important role as other capitals. Having a social capital means candidates are known by voters. Voters know them, physically and socially, which means they can make better assessment upon whether the candidates are worthy of being chosen or not. A candidate with social capital means he/she is not only known by the community, but also given the trust to become a leader (Pantouw, 2012: 7).

Social capital contains aspects of social structure that can facilitate the actions of actors involved, either as individuals or groups. Like other capitals, social capital is productive, which can be used to achieve a certain goal. Some of the main components of social capital include interaction and communication, common values and norms, networks, trust, solidarity, and norms of reciprocity (Fiisabiilillah, 2014: 212).

The relation between social capital and political capital was stated by Agusyanto (2011: 42-43), that the principles of social relations in social network of voters greatly influence and even determine the success of a regional head candidate in winning a local election. It is because by understanding the nature of the relationship, social relation can predict the situational logic (rules-norms) it creates, determine the type of control and exchanges useful for formulating programs and strategies for winning the right elections; formulate significant campaign material; and utilize actors who have important positions (broker/bridge, star/patron or cut points) as communication channels useful for the good image of a candidate and set the agreements to get maximum vote.

The relation between social capital and economic capital occurs when political funds (as economic capital) are not only used to finance the campaigns, but also to build relationships with their supporters, including to mobilize support from the campaign stage to the voting stage. The strong relationship between economic capital and social capital is able to push the winning team to interact optimally with the grassroots to get support, sympathy, and maximum vote in the elections.

The relationship between political capital, economic capital, and social capital in elections is conceptually expressed by several political experts under the name of "patronage and clientelism" (Aspinal and Sukmajati, 2015: 22-23). Patronage is an exchange of profits to gain political support, including the exchange of material with people support to cast their votes in the elections. Various methods are used to obtain political support, including by wrapping gifts as charities which contain religious sanctions or social generosity in the situation where community leaders must be involved; for example, by activating social norms about gratitude, reciprocity, and personal obligations, thus encouraging recipients to give gifts. Candidates also try to build clientelist relations with beneficiaries of this patronage politics or through trustworthy 
intermediaries, social networks, and those who are already have close personal relationship with voters.

Thus, it can be said that political competition is not merely determined by having political capital, but also specified by social capital and economic capital. Moreover, the relationship between these capitals influences the formation and presence of other capital accumulations.

\section{Research methods}

In this study, researchers use descriptive method with qualitative approach. Data collection is done through field studies and literature studies. Field studies as primary data sources are conducted through indepth interviews with purposively-selected informants, while literature studies as secondary data sources obtained by reviewing documents/literatures related to the problems examined.

Informants in this study are Regent of Pangandaran Regency period of 2016-2021, Deputy Regent of Pangandaran Regency period of 2016-2021, Chair of Pangandaran Regency Election Commission, political party leaders supporting Jeje-Adang in local election of Pangandaran Regency, volunteer representatives supporting Jeje-Adang, community leader, community groups representatives, and local mass media.

Three activities are carried out in data analysis technique, namely data reduction, data presentation, and data conclusion (Miles and Huberman, 1992: 16-21). In validating data, a triangulation technique is used to check data from different sources and different techniques.

\section{Jeje-Adang's Political Capital in Local Election of Pangandaran Regency in 2015}

Jeje-Adang's political capital in local election of Pangandaran Regency in 2015 can be seen through: (a) the coalition of political parties supporting Jeje-Adang; (b) political positions; (c) political actions that benefit and strengthen the position of political actors or political institutions; (d) political contracts; and (e) winning strategies.

Supporting from political parties (PDIP, Golkar Party, Democratic Party, and PKS) is influenced by Jeje-Adang's social capital of leadership figures, popularity, closeness to society, political gait, and experience. Great number of people who support the candidate, both individual and group through communities, are taken into consideration by political parties in carrying out and supporting the candidate. Jeje-Adang's figure is considered to be able to bridge different political parties. In addition, based on the results of a survey conducted by institutions, it shows that Jeje-Adang's electability is always higher than the other candidates. Based on those considerations, political parties decided to support Jeje-Adang as a candidate in local election of Pangandaran Regency in 2015. Thus, from the description above, it can be seen that political support is influenced by social capital.

Jeje-Adang's political capacity, experience, and position determine the support from political parties. Jeje-Adang has the ability to use their role as political and government officials to interact closely with the community, which means their social capital has been built long before local election of Pangandaran Regency was held. Their social capital is one of the reasons for major political parties in Pangandaran to support them, despite that this candidate is also party cadres with political experience, positions, and abilities considered good (credible).

Proper political actions can be beneficial to and strengthen the position of political actors or political institutions. It can be seen by Jeje's political behavior and actions during his career in politics and government in Ciamis, where he directly interacted and communicated with various group communities, especially Pangandaran community as part of Ciamis community. He often attended various community activities held by various groups of society, as well as conducting populist development programs when he served as deputy regent of Pangandaran, with programs such as giving fertilizer and subsidized seed for farmers, giving Raskin (rice for the unfortunates/poor), arranging land certificates at free costs for the poor, and program to increase business empowerment and economy of Pangandaran fishermen with the establishment of fishing communities.

Meanwhile, Adang's behavior and actions during his career in government and society are considered good because he was close to various communities, as well as being a successful entrepreneur who often helps the community. His role as a member 
of presidium of Pangandaran Regency, which was considered to have contributed to the expansion of Pangandaran region, was also considered positive and feasible to accompany Jeje as the regional leader in Pangandaran.

The establishment of political support for Jeje-Adang was not made explicit in written political contracts between candidates and political parties. However, it is more likely to be a joint commitment to create common perceptions of vision and mission and the realization of Jeje-Adang's political promises during the elections to become real programs if they were elected as Regent-Deputy Regent in Pangandaran.

There were also no political contracts between Jeje-Adang and various social communities and supporting volunteers because they have put their enormous trust in Jeje-Adang to be able to realize their political promises in accordance with the needs of Pangandaran people. The amount of public trust is Jeje-Adang's social capital which becomes the reason why there is no need for a political contract in the process of political support for the candidate in Pangandaran Regency election.

The winning strategy implemented by Jeje-Adang's winning team is based on their social capital. The magnitude of Jeje-Adang's social capital determines strategy approach carried out by the winning team, which then can be added to the accumulation of existing social capital. Political communication and consolidation are used to facilitate and accommodate community aspirations. The interaction between Jeje-Adang and various social communities was held directly as it was done with the winning teams at the district, sub-district, hamlet and RW levels, and the lowest part of community in socializing Jeje-Adang's flagship programs. Political consolidation often carried out between Jeje-Adang, the winning team, the volunteer team and various social communities in the campaign; while political communication carried out by the volunteer team in socializing Jeje-Adang's superior programs to their families, individuals, and various community groups in Pangandaran.

\section{Jeje-Adang's Economic Capital in Local Election of Pangandaran Regency in $\mathbf{2 0 1 5}$}

Jeje-Adang's economic capital in Pangandaran Regency Election in 2015 can be seen through aspects of: (a) obtaining funds from individuals (candidates), political parties, donations, etc.; (b) the acquisition of funds originating from the ownership of a private company or winning team, and (c) the use of campaign funds.

Reports on Revenue and Expenditures of Jeje-Adang's Campaign Fund in Pangandaran Regency Election in 2015 were based on the audit of Public Accountants Office shown in Table 1.

Table 1

Report on the Reception and Expenditure of Jeje-Adang's Campaign Funds

\begin{tabular}{|c|c|c|c|}
\hline \multirow{8}{*}{ A } & \multirow{3}{*}{$\begin{array}{l}\text { Description } \\
\text { Rp. } \\
\text { Balance of August } \\
24,2015\end{array}$} & \multirow{2}{*}{\multicolumn{2}{|c|}{$\begin{array}{c}\text { Jeje Wiradinata \& } \\
\text { Adang Hadari } \\
\text { Unit }\end{array}$}} \\
\hline & & & \\
\hline & & & \\
\hline & $\begin{array}{l}\text { Cash in a Special } \\
\text { Account }\end{array}$ & 7.000 .000 & 0 \\
\hline & $\begin{array}{l}\text { Cash in the } \\
\text { Treasurer }\end{array}$ & 1.000 .000 & 0 \\
\hline & Goods & 15.000 & 0 \\
\hline & Receivables & 5.985 .000 & 0 \\
\hline & Payable & 0 & 0 \\
\hline$B$ & Revenue & 865.003 .121 & 0 \\
\hline 1 & Candidate Pair & 100.000 .000 & 0 \\
\hline 2 & $\begin{array}{l}\text { Political Parties and } \\
\text { Coalition of Political } \\
\text { Parties (Total } \\
\text { Income) }\end{array}$ & 200.000 .000 & 0 \\
\hline 3 & $\begin{array}{l}\text { Donations from } \\
\text { Other Parties } \\
\text { (Individuals } \\
\text { Donations) }\end{array}$ & 565.000 .000 & 0 \\
\hline 4 & $\begin{array}{l}\text { Other Party } \\
\text { Donation Groups }\end{array}$ & 0 & 0 \\
\hline 5 & $\begin{array}{l}\text { Donations from } \\
\text { Other Parties } \\
\text { of Private Legal } \\
\text { Entities }\end{array}$ & 0 & 0 \\
\hline & Other Commitments & 3.121 & 0 \\
\hline C & Expenditures & 864.988 .200 & 0 \\
\hline 1 & $\begin{array}{l}\text { Operational } \\
\text { Expenditures }\end{array}$ & 839.493 .200 & 0 \\
\hline & a. Limited meetings & 448.493 .200 & 0 \\
\hline & $\begin{array}{l}\text { b. Face to face } \\
\text { meeting }\end{array}$ & 15.750 .000 & 0 \\
\hline & $\begin{array}{l}\text { c. Making ad } \\
\text { production in } \\
\text { printed mass media } \\
\text { and electronic mass } \\
\text { media }\end{array}$ & 74.725 .000 & 0 \\
\hline
\end{tabular}


d. Make campaign props design

e. Distribution of campaign material to the public

f. Other activities that do not violate the prohibition of campaigns and laws g. Etc

$85.518 .200 \quad 0$

2 Capital Expenditures

a. Vehicle

Purchases

b. Equipment

Purchases

c. Etc

3 Other Expenditures

a. Allowance for

Receivables

b. Debt Payments

D Balance of

December 5, 2015

Cash in a Special

Account

Cash in the

Treasurer

Goods

Receivables

Payable

More differences

(less)

Source: KPU of Pangandaran Regency, 2016.

Based on Table 1, it can be seen among other things that campaign funds come from personal financial support (Jeje-Adang), political parties, donations, and others. In the component of Jeje-Adang's campaign funding revenue, donations from other parties (individuals) made the largest contribution of $65 \%$ to the total campaign financial input (KPU, Pangandaran Regency Election Commission, 2016: 61) which was obtained from volunteers and communities in the name of individual donations and not on behalf of the group or a business institution. The amount of donations from other parties (individuals) showed the magnitude of community support for Jeje-Adang. Community support is social capital that shows public trust in candidates. Thus, Jeje-Adang's social capital contributed significantly to their economic capital in the election.

Revenue of campaign funds as one aspect of Jeje-Adang's economic capital showed that although Adang was known as a successful entrepreneur, the community still cared providing financial support for the success of Jeje-Adang in local election of Pangandaran Regency.

Funding support from communities are the biggest donations to the candidate. Community support is a social capital that formed and raised the candidates. It can't be separated from the figure of Adang as an entrepreneur (economic capital) that used to build good relationships and interactions (by providing social assistance, especially for disadvantaged people) which frequently carried out long before Pangandaran regional election was held.

Adang's social and economic capital also contributed to the acquisition of support from political parties (political capital). His figure as an entrepreneur with high social capital influences political support from political parties that have been with him for one year before the nomination announced. His figure of entrepreneur is considered to be able to drive the political machinery in political contestation.

As an entrepreneur, he is close to and trusted by the community which influences the political parties that support him. Big support from community is social capital that contributed to the vote acquisition of Jeje-Adang in local election of Pangandaran Regency in 2015.

The use of campaign funds in Pangandaran Regency election in 2015 showed there was a relationship between Jeje-Adang's economic capital and JejeAdang's social capital in Pangandaran election, where most of the candidate campaign funds were from individual community. It means social capital contributes to the candidates' economic capital. Meanwhile, the use of campaign funds is influenced by conditions of social capital (community support) including support from social community and volunteer teams, so that limited meeting campaign held are considered the most effective efforts to consolidate and coordinate the winning teams with supporters.

Accordingly, the conditions of social capital and ownership (utilization) of economic capital affect the winning strategy (one of the elements of political capital) carried out by the winning team of Jeje-Adang in local election of Pangandaran Regency in 2015. 


\section{Jeje-Adang's Social Capital in Local Election of Pangandaran Regency in 2015}

Jeje-Adang's social capital in the election can be seen through aspects of: (a) leadership figures of candidates due to their capacity, capability, and integrity, (b) community trust in candidates, (c) social interaction between candidates and supporters, and (d) the existence of social networks (social communities) and volunteer teams.

From the aspect of leadership figure, it showed that Jeje-Adang is well known to the public. They are considered good candidate, leaders who close to Pangandaran's community, has political and governmental capacity which can be seen from their political and government's experience. In addition, both of them are also assessed to have good integrity in their work as community leaders, political leaders, officials in government, and members of society. It makes them trusted and supported by the community (both individual communities and community groups) to become candidates for regional leaders in Pangandaran Regency. In other word, both have the considerable social capital to compete as candidate pairs in local election of Pangandaran Regency in 2015. This magnitude of community support is one of the reasons why Jeje-Adang pair is supported by a coalition of major parties in Pangandaran (PDIP, Golkar Party, Democratic Party, and PKS).

Jeje-Adang's social capital of public trust was not established over one night or only during the election process. It is gradually achieved based on the closeness of physical, social, and emotional, which has been built up several years prior to the election. This social capital of public trust is one of the reasons for political parties (that affects the acquisition of political capital) to support Jeje-Adang as the candidate, which then greatly contributed to the candidate's victory in local election of Pangandaran Regency in 2015.

Social interactions carried out by Jeje and Adang with Pangandaran community became one of the factors in the formation of their social capital as long as they are Pangandaran citizens or community leaders and living their career in politics and government, which have been built several years before the election. Social interaction is one form of political capital utilization carried out by Jeje when serving as Chair of Regional Representative Council of Ciamis Regency and Deputy Regent of Ciamis Regency before Pangandaran was expanded and separated from Ciamis Regency. The same thing was done by Adang through his (utilization of) economic capital as an entrepreneur in Pangandaran who often provided assistance to people in need and actively involved in various community activities in Pangandaran.

Social networks (social communities) and volunteer teams are the elements that influence the optimization of JejeAdang's social capital. The interaction with and support from social communities and volunteer teams in the elections help the candidate's winning team in socializing and conveying Jeje-Adang's vision, mission, and superior programs to the community. Political consolidation and interaction with social networks (social community groups) also shows the magnitude of Jeje-Adang's social capital in the election. It influences the implementation of their winning strategy (as one of the elements in optimizing political capital) in the election, which is also related to the use of candidate's campaign funds (utilization of economic capital) to finance campaigns in the form of limited meetings with communities.

Based on the description above, the relation between those capitals can be seen from the role of candidate's social capital to the optimization of political and economic capital in the contestation, in which the process of political capital ownership is strongly influenced by social capital ownership. Likewise, the process of economic capital ownership is strongly influenced by social capital ownership.

However, the candidate's social capital emerged and built long before political contestation began, where the process of utilizing political capital occurred by interactions and building relationships and closeness (physical, social and emotional) with various community groups (from their work as officials in government) and ended up gaining community trust and support (social capital). Likewise, the use of economic capital (the candidate as entrepreneurs) that has been possessed long before the political contestation, where he was frequently interacting and providing materials to assist the community and finally gained public trust (social capital). Thus, the relationship between political capital, economic capital, and social capital of the candidate in political contestation is the use of one capital to 
optimize other capitals which can influence and determine the success of candidate to win political contestation.

\section{Field Findings}

Field findings in the study of JejeAdang's capital relations in local election of Pangandaran Regency in 2015 are as follows:

\section{The Candidate's Branding (Personal Branding)}

The candidate's branding (especially Jeje) is a form of political strategy proposed by Jeje's political colleague when he still worked as a politician in Ciamis Regency. It was carried out several years before the election, when the idea of the expansion of Pangandaran as the new autonomous region was proposed and studied by various stakeholders. The branding process was initiated when Jeje worked as Deputy Regent of Ciamis Regency, by performing political communication to Pangandaran community (which then became one of the important factors in marketing the candidate), and he ended up became so popular in communities.

Armed with and having social capital he had built since 1999, the political communication process was carried out well by Jeje as Deputy Regent of Ciamis Regency, including implementation of populist development and government programs for Pangandaran people which was still part of Ciamis Regency at that time. This political communication strategy succeeded in bringing Jeje closer to various community groups and made them considered that he would be able to understand the conditions and characteristics of Pangandaran community.

The popularity of Jeje can be seen in the survey results on the popularity of Candidates of Pangandaran Regent in 2015 based on the survey of "Political Behavior and Perception of the Pangandaran District Community Facing the Simultaneous Local Election in 2015", conducted and released by Lamda Survey Indonesia (http://www. lamda-ksi.com/2015/11/tingkat-popularitascalon-bupati.html). The survey uses a multistage random sampling method by taking respondents of 750 people who are spread proportionally in Pangandaran district of West Java province. The elections survey was released in September 2015. According to the survey results, the popularity of each candidate (individual) who will compete in the local election of Pangandaran Regency can be seen in the Table 2.

\section{Table 2}

Level of Candidates Popularity in Local Election of Pangandaran Regency

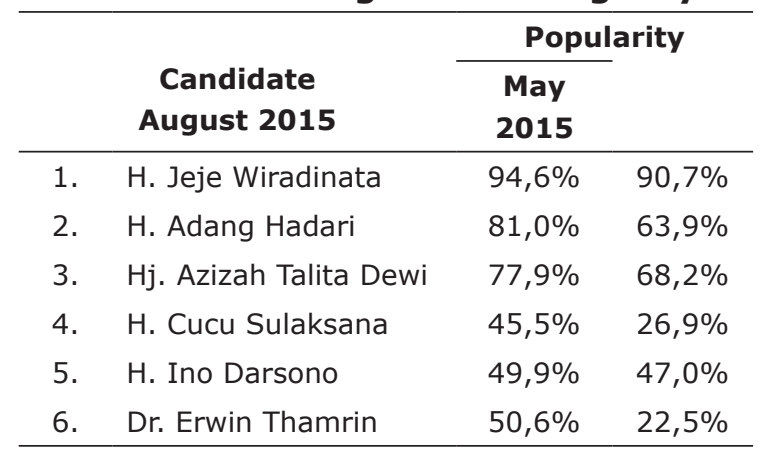

Source: Survey Lamda Indonesia, 2015.

Based on Table 2 above, there is a comparison of candidates' popularity in the first survey held in May 2015 with the next survey held three months later (August 2015), which has increased the popularity of each candidate. This increase was not only triggered by the incessant socialization of each team, but also because of the candidates who had officially registered to local election commission.

For the popularity level of regent candidates, Jeje was dominated with a percentage of $94.6 \%$ of respondents who knew him. Jeje's high popularity compared to other candidates is his social capital in Pangandaran regional election. One of the important factors that made him popular was the political communication strategy he successfully implemented.

The success of communication strategy can be assessed effective if it considers all the relevant communication elements. The relationship between related communication elements is stated by Appelbaum \& Anatol quoted by Rachmiatie et al $(2013,216)$, which includes: (1) The source-receiver relationship is a relationship determined by the purpose of communication activity; (2) The sourceenvironment relationship refers to social, political, and cultural effects on the speaker in certain communication situations; (3) The receiver-environment relationship refers to social, political, and cultural effects on a set of psychological conditions of the recipient; (4) The receiver-message relationship refers to the effect of communication appears on the recipient caused by the form, content, and presentation of the message. Thus, the 
main element for establishing an effective and efficient political communication strategy depends on the situation and environment when political communication takes place. This will be determined by the patterns of relations between political actors involved (2013: 126).

Personal branding supported by effective political communication strategy has succeeded in building the magnitude of Jeje's social capital as one of the factors that influenced Jeje-Adang's political capital and economic capital in the election of Pangandaran Regency.

\section{Patronage Relationship}

Another finding is patronage relationship in the acquisition of Jeje-Adang's social capital, where the emerging of Jeje-Adang's social capital is due to high trust and closeness of physical, social, and emotional between the candidate and supporters (people who depend on the pair). Jeje-Adang are well known and trusted by Pangandaran people to become their leaders. It was a form of reciprocation from what people have received and felt so far or from what Jeje-Adang have given to the community. This physical, social, and emotional closeness can finally be seen through the support of community for JejeAdang in the form of financial support for campaign funds, particularly and mostly from individual donations. This can be viewed in the Table 3.

Table 3

Revenue of Jeje-Adang's Campaign Fund

\begin{tabular}{|c|c|c|c|}
\hline \multirow{2}{*}{\multicolumn{2}{|c|}{$\begin{array}{l}\text { Description } \\
\text { Rp. }\end{array}$}} & \multirow{2}{*}{\multicolumn{2}{|c|}{$\begin{array}{l}\text { Hj. Jeje Wiradinata \& } \\
\text { H. Adang Hadari } \\
\text { Unit }\end{array}$}} \\
\hline & & & \\
\hline & Revenue & & \\
\hline 1 & Candidate Pair & 100.000 .000 & 0 \\
\hline 2 & $\begin{array}{l}\text { Political Parties } \\
\text { and Coalition of } \\
\text { Political Parties } \\
\text { (Total Income) }\end{array}$ & 200.000 .000 & 0 \\
\hline 3 & $\begin{array}{l}\text { Donations from } \\
\text { Other Parties } \\
\text { (Individuals } \\
\text { Donations) }\end{array}$ & 565.000 .000 & 0 \\
\hline 4 & $\begin{array}{l}\text { Other Party } \\
\text { Donation Groups }\end{array}$ & 0 & 0 \\
\hline 5 & $\begin{array}{l}\text { Donations from } \\
\text { Other Parties } \\
\text { of Private Legal } \\
\text { Entities }\end{array}$ & 0 & 0 \\
\hline
\end{tabular}
Other
3.121
0
Commitments
Total Revenue
865.003.121 0

Source: KPU of Pangandaran Regency, 2016. Based on table 3, revenues of JejeAdang's campaign fund mostly derived from donations of other parties (individual donations) with the percentage of $65 \%$ from total revenues. Individual community voluntarily provides campaign fund assistance for Jeje-Adang as a realization of their support.

The relationship between candidates and their supporting communities can be seen as a form of patronage relation. The patronage relation between two parties is established in a way that the community is very dependent on Jeje-Adang as the newly formed regional leader because the pair is socially and emotionally close to the community as a result of long-standing interactions and mutual relation between them.

The patronage relationship can be seen through Jeje-Adang's social capital acquisition by activating social norms about thank-you, reciprocity, and personal obligations, thus encouraging recipients of gifts to repay the gifts (Aspinal and Sukmajati, 2015: 22- 23).

\section{Rational Choice}

The relationship between Jeje-Adang's social capital and political capital as well as economic capital can also be seen through a rational choice approach for some people. This is indicated by the tendency of most people to choose Jeje-Adang because they are considered to have political capacity, political experience, has a good track record in politics and government, and capable of understanding the conditions, potentials, problems, and characteristics of the community and Pangandaran as a new autonomous region. In other words, JejeAdang is rationally considered capable of carrying and building Pangandaran to be a better place after being expanded from Ciamis. The community believe that the candidate pair has the ability to be regional leaders and they are better than other candidates.

The findings of rational choice approach in the context of capital relations can clearly be seen through the aspects of catalatics (exchange) and homo economicus (humans who maximize their utility) as stated by 
Rachbini (2006: 68-83) that the two will always make reciprocal relations regarding what is received and what is given. The aspect of catalatics (exchange) can be seen from the support of individuals of community and various social communities (material and non-material) for the candidate, with the hope that superior programs (political promises) of Jeje-Adang concerning the construction of infrastructure, public facilities and community welfare will be realized if the pair is elected in regional election. The homo economicus aspect is shown by the hope of various community groups towards Jeje-Adang as the leaders of newly expanded Pangandaran region to be able bring progress and improvement in community's welfare, as well as bridging and overcoming socioeconomic problems in accordance with regional conditions and characteristics of Pangandaran communities.

This condition can be seen through the acceptability level (community acceptance) of candidates, one of which is obtained through a survey conducted by Lamda Survey Indonesia, as shown in the Table 4.

\section{Table 4 \\ Acceptability level of Candidates in Local Election of Pangandaran Regency in $\mathbf{2 0 1 5}$}

\begin{tabular}{|l|l|r|l|}
\hline \multicolumn{2}{|c|}{$\begin{array}{c}\text { Candidate } \\
\text { August 2015 }\end{array}$} & \multicolumn{2}{c|}{ Acceptability } \\
\cline { 3 - 4 } & $\begin{array}{c}\text { May } \\
2015\end{array}$ & \\
\hline 1. & H. Jeje Wiradinata & $83,9 \%$ & $84,4 \%$ \\
\hline 2. & H. Adang Hadari & $75,0 \%$ & $93,4 \%$ \\
\hline 3. & Hj. Azizah Talita Dewi & $73,0 \%$ & $85,9 \%$ \\
\hline 4. & H. Cucu Sulaksana & $43,9 \%$ & $72,3 \%$ \\
\hline 5. & H. Ino Darsono & $55,8 \%$ & $76,5 \%$ \\
\hline 6. & Dr. Erwin Thamrin & $59,0 \%$ & $77,4 \%$ \\
\hline
\end{tabular}

Source: Survey Lamda Indonesia, 2015.

Based on table 4, it can be seen that public acceptance (acceptability level) for candidates in local election of Pangandaran was above $70 \%$ (survey conducted in May 2015). While based on survey conducted in August 2015, after all the candidates were officially announced by KPUD, the community acceptance (acceptability level) for Jeje took the highest level, and the second one was Adang. Jeje and Adang were the candidates for the Regent-Deputy Regent that eventually won the election.

The high level of public acceptance for Jeje-Adang can be seen through a rational choice approach of homo economicus aspect (maximizing its utility aspects). By maximizing this aspect, the community hopes that Jeje-Adang will be able to understand and accommodate the aspirations developed in the community if they were elected as RegentDeputy Regent of Pangandaran. Furthermore, with their authority, the candidate pair is hoped to be able to create and run the development program based on community aspirations. In other words, the community chooses Jeje-Adang because the candidate is considered to be able to provide benefits in carrying out their duties and authority as the Regent-Deputy Regent and will have a better impact on improving the lives and welfare of the community.

\section{Conclusion}

The relationship between Jeje-Adang's political capital, economic capital, and social capital in local election of Pangandaran Regency in 2015 can be seen through the utilization of Jeje-Adang's social capital to obtain and optimize their political capital and economic capital. On the contrary, JejeAdang's social capital was awaked because of the utilizing of their political capital in politics and government by building relationships, interactions, closeness (physical, social and emotional) with various community groups in order to foster communities trust and supports. Likewise, there is the utilization of candidate's economic capital (Adang as an entrepreneur) which has been carried out long before political contestation takes place. Adang often interacts and provides material assistance to the community to build and foster public trust for him. Thus, the relationship between political capital, economic capital, and social capital carried out by candidates in political contestation in the form of capital use to optimize other capitals (and vice versa) can influence and determine the success of the candidate to win the political contestation.

\section{References}

Agusyanto, R. (2011). "Dukungan Politik dan Jaringan Komunikasi Sosial Kasus Pemilihan Kepala Daerah Banjarbaru, Kalimantan Selatan". Journal Communication Spectrum, Vol. 1 No. 1 (Februari - Juli 2011), p. 41-54.

Arwantinna, M. (2013). jmipm. studentjournal.ub.ac.id/index.php/ jmipm/.../2"Kemenangan Anton-sutiaji 
(Aji) Dalam Pemilihan Walikota (Pilwali) Kota Malang Tahun 2013"

Aspinal, E. and M. Sukmajati. (2015). Politik Uang di Indonesia: Patronase dan Klientelisme pada Pemilu Legislatif 2014. Yogyakarta: Polgov.

Birner, R. and H. Wittmer. (2007). Coverting Social Capital into Political Capital. How do local communities gain political influence? A theoritical approach and empirical evidence from Thailand and Columbia. Paper submitted to the 8th Biennial Conference of the International Association for the Study of Common Property (IASCP).

Booth, J.A. and Richard Patricia Bayer. (1997). Civil Society, Political Capital, and Democratization In Central America. Prepared for presentation at the XXO International Congress of the Latin American Studies Association, Guadalajara, Mexico.

Bourdieu, P. (1986). "The forms of capital". In J. Richardson (Ed.) Handbook of Theory and Research for the Sociology of Education. New York: Greenwood, p. 241-258.

Casey, K. L. (2008). Defining Political Capital: A Reconsideration of Bourdieu's Interconvertibility Theory. Paper Presented at the Illinois State University Conference for Students of Political Science. University of Missouri-St. Louis.

Fiisabiilillah, D. F. dkk. (2014). "Peran Modal Sosial dalam Kerjasama Antardaerah Kartamatul". Jurnal MIMBAR, Vol. 30 No. 2 (Desember 2014), p. 209-219.

Haryatmoko. (2011). Habitus dan Kapital dalam Strategi Kekuasaan - Teori Stukturisasi Piere Bourdieu dengan Orientasi Budaya, Paper Presented at Pascasarjana Sosiologi UI (26/9/2010) dan di Pasca Sarjana Ilmu Budaya UI, Depok (September 2011).

KPU Kabupaten Pangandaran. (2016).
Laporan Penyelenggaraan Pemilihan Bupati dan Wakil Bupati Pangandaran Tahun 2015.

Miles, M. B dan M. Huberman. (1992). Analisis data Kualitatif. Jakarta: UI Press.

Marijan, K. (2010). Sistem Politik Indonesia Konsolidasi Demokrasi Pasca Orde Baru. Jakarta: Kencana Prenada Media Group.

Marijan, K. (2006). Demokratisasi di Daerah: Pelajaran dari Pilkada Secara Langsung. Surabaya: Eureka.

Nurhasim, M. dkk. (2003). Konflik antar Elit Politik Lokal dalam Pemilihan Kepala Daerah. Jakarta: Pusat Penelitian Politik (P2P) LIPI.

Pantouw, S. M. I. (2012). Modalitas Dalam Kontestasi Politik (Studi tentang Modalitas dalam Kemenangan Pasangan Hanny Sondakh dan Maximiliaan Lomban pada Pemilukada di Kota Bitung Sulawesi Utara tahun 2010). Tesis. Semarang: Universitas Diponegoro.

Putra, Y. R.. (2012). Optimalisasi Modal Politik Pasangan Ismet Amzis-Harma Zaldi pada Pemilihan Umum Kepala Daerah Kota Bukittinggi Tahun 2010. Universitas Andalas.

Rachbini, D. J. (2006). Ekonomi Politik dan Teori Pilihan Publik. Bogor: Ghalia Indonesia.

Rachmiatie, A., dkk. (2013). "Strategi Komunikasi Politik dan Budaya Transparansi Partai Politik". Jurnal MIMBAR, Vol. 29 No. 2 (Desember, 2013), p. 123-132.

Rasyid, A. (2012) repository.ugm.ac.id/86683/ Modalitas dan strategi pemenangan Pilkada pada pasangan kandidat Drs. $\mathrm{H}$. Yusriansyah Syarkawi,M.Si dan Drs. H. Azhar Bahruddin, M.AP dalam Pilkada 2010 di Kabupaten Paser Kalimantan Timur,

Sahdan, G. dan M. Haboddin (editor). (2009). Evaluasi Kritis Penyelenggaraan Pilkada Di Indonesia. Yogyakarta: IPD. 